\title{
THE DIFFERENCE IN THE GROWTH AND DEVELOPMENT OF SCHOOL BOYS AND GIRLS AND RELATED FACTORS
}

Alyoshi KAWAHATA, Tamotsu YAGI

School of General Education, University

of Kyoto, Kyoto

Fumio YOSHIOKA

Women's College of Kyoto, Kyoto

\section{Introduction}

The physical status of school boys and girls in Japan has been rising recently, as indicated by the Statististical Report on School Health issued by the Ministry of Education and other reports. And the phenomenon that their secondary sex characteristics are also accelerated has been pointed out and studied by some researchers.

For the phenomena of the growth and development of boys and girls, the following factors will be taken into consideration; that the economical'status of Japan and the nutritional conditions of the people have been elevated, and the environment and the standards of living have been improved and so on.

On the other hand, we can see differences between some geographic regions in terms of physical status and the age of the emergence of their secondary sex characteristics, despite of the fact that the over-all physical status of boys and girls in Japan has risen.

We will discuss factors of the phenomenon of the physical growth and development of boys and girls, and regional differences of the growth and devlopment.

In the report of the Ministry of Eucation, it is shown that the phsycal status of school children of Kagoshima Prefecture, which is the southmost prefecture in Japan, is the lowest (Table 1).

We have investigated the physical growth and develoment of the school boys and girls in this prefecture.

Table 1-1. Maximum and Minimum of the Average Physical Status of The Prefectures in Japan

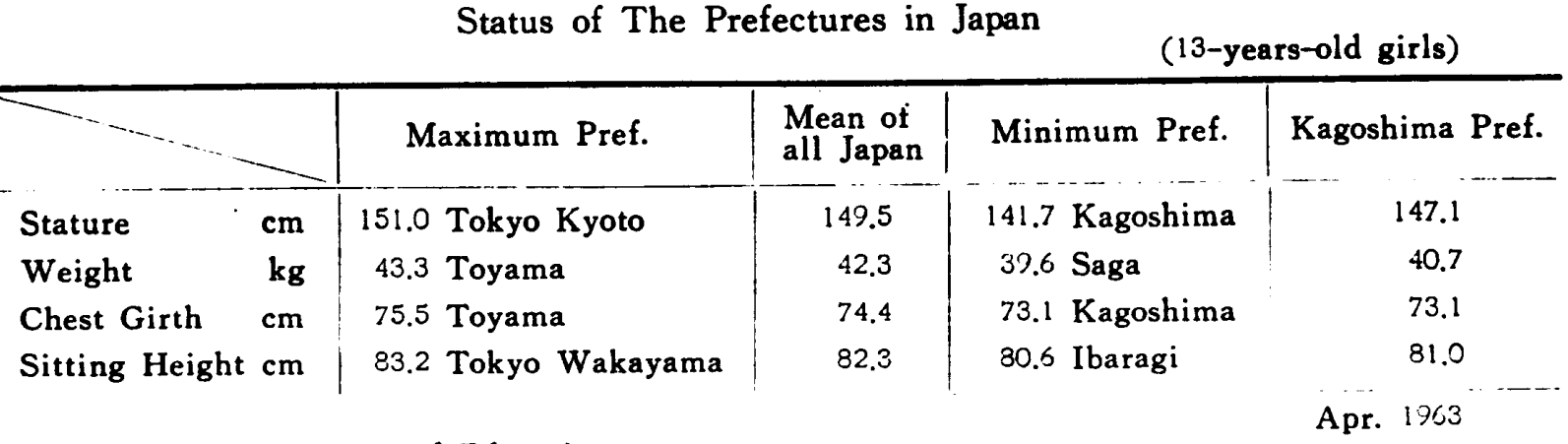

Source: The Ministry of Education 
Table 1-2 Maximum and Minimum of the Average Physical Status of the Prefectures in Japan

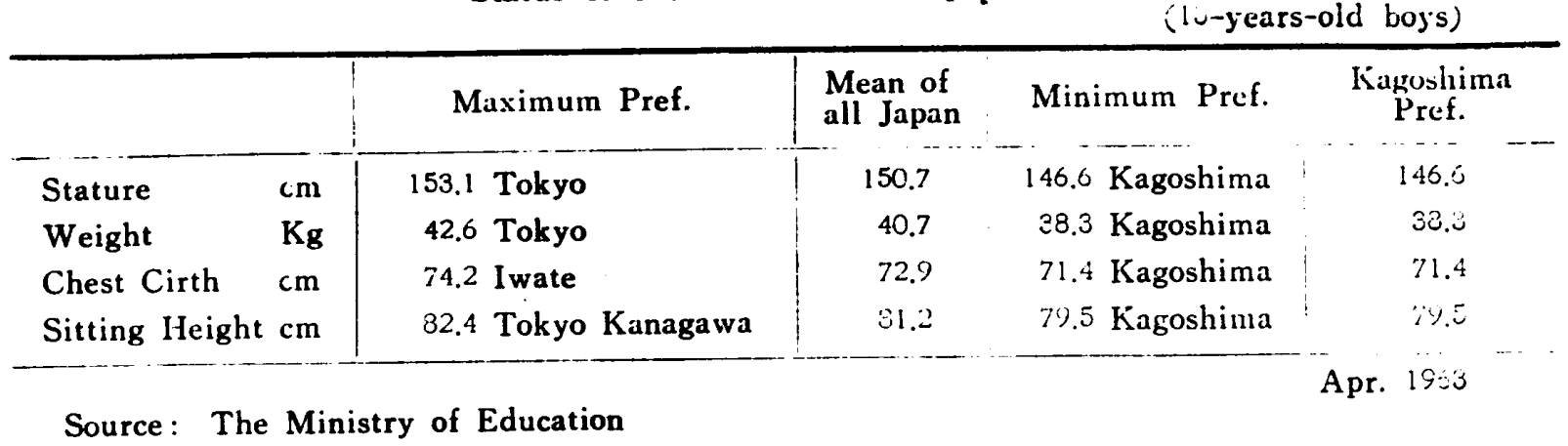

\section{Methods of Study}

The study is made for the most part by means of a questionaire in adddition to utilizing the periodic school health examinations. The items of the questionaire are: 1. Name, age, school etc; 2. Living area (city or country, residetial quarter or shopping quarter, etc.); 3. Financial conditions of family; 4. Occupation of head of family; 5. Physical status (height, weight, chest girth, sitting height) —- the result of the periodic school health examination;6. Physical exercise : 7. Physical labor; 8. Daily timetable; 9. Menarche or Mutation; 10 Nutrional condi- tion (the amount of milk, egg, meat, fish, beans, etc. eaten).

For these items, we questioned pupils themselves. However, for the financial conditions of family, the school record and I.Q., we questioned their teachers.

The subjects of inquiry are the junior high school boys and girls. In this study, we will take up mainly the thirteen-years-old (i.e. second grade of junior high school) boys and girls at three junior high schools (A-B.C.) in Kagoshima City.

\section{Results and Dissussion}

(1) Just as there are regional differences in the physical grwoth and development of children in Japan, we are able to recognize differences in the growth and development of boys and girls between three selected schools in the city (see Table 2).

Table 2-1. Physical Status at the Three Junior High Schools in Kagoshima (13-years-old girls)

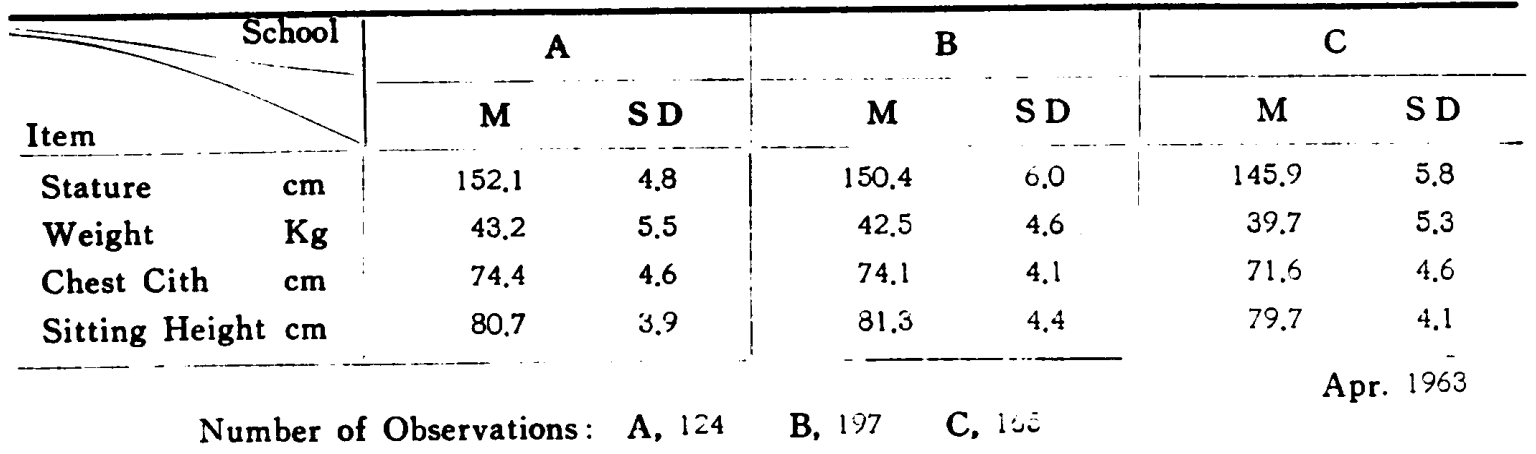


Table 2-2. Physical Status at the Three Junior High Schools in Kagoshima

(13-years-old boys)

\begin{tabular}{|c|c|c|c|c|c|c|}
\hline School & & & & & & \\
\hline Item & $\mathbf{M}$ & S D & $\mathbf{M}$ & S D & $\mathbf{M}$ & S D \\
\hline Stature & 154.2 & 8.4 & 150.4 & 6.8 & 147.3 & 7.4 \\
\hline Weight & 43.0 & 8.2 & 40.5 & 5.0 & 38.5 & 5.8 \\
\hline Chest Cith cm & 73.8 & 6.0 & 73.3 & 4.7 & 70.4 & 4.2 \\
\hline Sitting Height $\mathrm{cm}$ & 81.9 & 4.7 & 80.3 & 4.5 & 78.8 & 5.4 \\
\hline
\end{tabular}

Number of Observations: A, $122 \quad$ B, $197 \quad$ C, 165

First, let us consider stature. The average stature of girls of " $A$ " school is the hghest, at $152.1 \mathrm{~cm}$, that of " $\mathrm{B}$ " school, $25.4 \mathrm{~cm}$ is next and that of " $\mathrm{C}$ " school is the lowest, at 145.9 $\mathrm{cm}$. The difference in the average stature of girls between " $\mathrm{A}$ " junior high school and " $\mathrm{C}$ " junior high school is $6.2 \mathrm{~cm}$.

Then, when compared with the prefecture-wide average (Table 1), those of " $A$ " and " $B$ " school are fairly higher, and that of " $\mathrm{C}$ " school is almost the same or lower. Particularly, the average stature of $\mathrm{A}$ school pupils are higher than those of Tokyo and Kyoto which are the highest in Japan.

The same tendency is observed for both boys and girls. For weight, chest of girth and sitting height, there is a tendency similar to that observed in stature for both boys and girls. For instance, the average weight of girls of " $A$ " school $43.2 \mathrm{~kg}$. is the heaviest, that of " $\mathrm{B}$ " school is next, 42.5kg., and that of " $\mathrm{C}$ " school is the third.

It might be thought that the physique of children of Kagoshima Prefecture is the lowest of all prefectures in Japan because of the geographical or climatic factors in this southmost prefecture. However, the case of " $A$ " school suggests other contributing factors. " $A$ " school is a junior high school attached to the university, " $B$ " school is a junior high school at the central part of the city, and " $\mathrm{C}$ " school is a junior high school in the suburbs of the city.

(2) For the sexual maturity; the age of the emergence of menarche in girls and the mutation in boys, it is found that maturity at " $A$ " school is the earliest, at " $B$ " school, it is second and at "C" school, it is latest, for both boys and girls. (see Table 3)

Table 3-1. Percentage of Emergence of Menarche

\begin{tabular}{|c|c|c|c|}
\hline $\begin{array}{ll} & \text { school } \\
\text { girls } & \\
\end{array}$ & $\mathbf{A}$ & B & C \\
\hline Have Menarche & $83.9 \%$ & $83.2 \%$ & $61.7 \%$ \\
\hline Have not had Menarche & 16.1 & 16.8 & 38.3 \\
\hline
\end{tabular}

Number of Girls: A, 124 B, $197 \quad$ C, 165
Table 3-2. Percentage of Emergence of Mutation

\begin{tabular}{l|c|c|c}
\hline \multicolumn{1}{|c|}{ school } & A & B & C \\
\hline boys & & & \\
\hline Mutation Occurred & $52.5 \%$ & $43.7 \%$ & $43.6 \%$ \\
M. Not-occurred & 42.6 & 49.2 & 52.7 \\
No Answer & 4.9 & 7.1 & 3.4 \\
\hline
\end{tabular}

Number of Boys: A, 122 B, 197 C, 165 
For mutation, we asked loys if their voices had changed, in orcler lo determine if sexual changes had occured. Regarding sexual maturity, as wellas physique, there is also a problem of whether early maturity is better than late maturity. But, at the age investigated, those who matured earlier had higher I.Q. ratings and school records than those who matured later.

In general, the boys and girls whose physical status are superior have earlier emergence of secondary sex characteristics and better intelligence than those whose physical status are inferior.

(3) The occupations of the students' families are presented with percentages of each occupations in Table 4. 'Salaried worker' indicates the so-called salaried man and includes teachers, civil servants, company employees, etc. 'Medical' indicates doctors and other medical men, pharmaceutists, nurses and maternity-nurse.

Table 4-1. Occupation of Family (girls) (\%)

\begin{tabular}{c|c|c|c|c|c|c|c}
\hline $\begin{array}{c}\text { Occup. } \\
\text { School }\end{array}$ & $\begin{array}{c}\text { Salaried } \\
\text { worker }\end{array}$ & $\begin{array}{c}\text { Commercial } \\
\text { and Industry }\end{array}$ & Agricultural & Labor & Medical & Other \\
\hline A & $52.0 \%$ & 26.4 & 0 & 0 & 14.7 & 6.9 \\
B & 37.8 & 37.0 & 0.8 & 10.9 & 4.0 & 10.1 \\
C & 17.7 & 11.4 & 65.8 & 3.8 & 0 & 1.3 \\
\hline
\end{tabular}

Table 4-2. Occupation of Family (boys) (\%)

\begin{tabular}{c|c|c|c|c|c|c}
\hline Occup. & $\begin{array}{c}\text { Salaried } \\
\text { worker }\end{array}$ & $\begin{array}{c}\text { Comercial } \\
\text { and Industry }\end{array}$ & Agricultural & Labor & Medical & Other \\
\hline School & $55.7 \%$ & 29.7 & 1.6 & 0 & 10.7 & 4.1 \\
A & 50.5 & 37.7 & 3.2 & 1.1 & 4.3 & 3.2 \\
B & 27.3 & 6.7 & 63.6 & 1.8 & 0 & 0.6 \\
\hline
\end{tabular}

Among the "A" school girls, 52\% of their parents are in the 'salaried' category, which claims more parents than any other category; the commercial and industry, about $26 \%$, third is 'medical' and none are employed in agricuitural work. In " $B$ " school students, salaried parents are fewer than the " $\mathrm{A}$ " school; about $3 \%$, the next is 'commercial and industry', 37 $\%$, more than the " $A$ " school and 'agricultural' is about $1 \%$. In the " $C$ " school "agriculthral' takes the greater part of it. As for the boys, there is a same tendency to the girls.

(4) In table 5, the financial condition of the chirdren's families is summarized. ' $A$ ' is case of well-off, 'B' is average, 'c' is poor and ' $d$ ' indicates that families received aid from soc. iety.

In short, the families of the $A$ school children are of the upper category and middle category, B school childrens' families are of the upper-middle and lower-middle category. Most of $C$ school pupils'families are in the middle category, but there are more in the lower category than in the cas of $B$ shool. The economial order of their families is $A, B, C$. 
Table 5-1. Economical Status of [eamily Girls;

\begin{tabular}{|c|c|c|c|c|}
\hline $\begin{array}{r}\begin{array}{r}\text { economical } \\
\text { class } \\
\text { school }\end{array} \\
\end{array}$ & a & b & c & d \\
\hline A & $46.2 \%$ & 58.2 & 0.8 & 0 \\
\hline B & 32.9 & 65.1 & 0.7 & 1.3 \\
\hline C & 5.6 & 68.5 & 12.6 & 13.3 \\
\hline
\end{tabular}

a : well-off $b$ : average $c:$ poor

$\mathrm{d}$ : receiving aid
Table 5-2. Ecnomical Status of Family

(Boys)

\begin{tabular}{r|c|c|c|c|l}
\hline $\begin{array}{r}\text { economical } \\
\text { class }\end{array}$ & a & b & c & d \\
school $\begin{array}{c}\text { cla } \\
\text { A }\end{array}$ & $31.1 \%$ & 68.9 & 0 & 0 \\
B & 11.3 & 82.6 & 4.1 & 2.0 \\
C & 4.9 & 71.5 & 14.5 & 9.1 \\
\hline
\end{tabular}

a: well-off $b$ : average $c$ : poor

$\mathrm{d}$ : receiving aid

(5) The performance of physical labor or domestic work is shown in Table 6. It is clearly evident that a large percentage of the children of "C" school work, and their working hours are longer than those of students of any other school. The extent of labor as is done by students of "C" school will become a factor to disturb the physical growth and development of children. The excess labor in the agricultural district will clisturb the phy. sical growth and development of children.

Table 6-1. Physical Labor or Domestic Help

$\left.\begin{array}{c|c|c|c}\hline \text { School } & \text { Working } & \text { Not working } & \text { Working Hours } \\ \text { A } & 16.7 \% & 33.3 \% & 1.03 \mathrm{hr} \\ \text { B } & 12.8 & 87.2 & 1.50 " \\ \text { C } & 70.8 & 29.2 & 1.76 "\end{array}\right\}$ Hours

See below

As to Working

Table 6-2. Physical Labour or Domestic Help

(Boys)

\begin{tabular}{|c|c|c|c|c|}
\hline School & Answer & Working & Not working & Working Hours \\
\hline & A & $56.6 \%$ & $43.4 \%$ & $0.76 \mathrm{hr}$ \\
\hline & B & 47.2 & 52.8 & $1.16 "$ \\
\hline & C & 73.1 & 22.9 & $1.18 "$ \\
\hline
\end{tabular}

(6) For physical exercise, we asked if pupils belong to the sports club in school or not. (see Table 7) More of children of A school, whose physical status is excellent, belong to a sport club than those of $B$ school. The kinds of clubs are volleyball, tennis, basketball, baseball, gymnastics, kendo, judo, etc..

(7) For nutritional conditions, we inquired as to the amount of food such as milk, eggs, meat, fish, beans, and so forth, which they had eaten during the week prior to questioning. Table 8 shows conspicuously that the food intake status of A school students is better than 
Table 7-1. Physical Exercise

(Girls)

\begin{tabular}{c|c|c|c}
\hline School & Answer & Y & N \\
A & $19.4 \%$ & $80.6 \%$ \\
B & 10.3 & 89.7 \\
C & 10.1 & 89.9 \\
\hline
\end{tabular}

Y : belong to the club

$\mathrm{N}$ : do not belong to the club
Table 7-2. Physical Exercise

(Boys)

\begin{tabular}{ccc|c}
\hline School & Answer & \multicolumn{1}{c|}{$\mathrm{Y}$} & $\mathrm{N}$ \\
\hdashline A & $35.2 \%$ & $64.8 \%$ \\
B & 31.0 & 69.0 \\
C & 31.5 & 68.5 \\
\hline
\end{tabular}

$\mathrm{Y}:$ belong to the club

$\mathrm{N}$ : do not belong to the club

Table 8-1. Nutritional Status

(Girls)

\begin{tabular}{rrr|l|l|l|l|l}
\hline School & $\ldots$ & Food & Milk & Eggs & Meat & Fish & Bean \\
\hline & A & 5.0 bottle & 5.7 & 4.4 times & 3.3 times & 3.5 times \\
B & 1.6 & 4.2 & 3.3 & 3.2 & 2.3 \\
C & 1.1 & 3.2 & 1.9 & 3.1 & 2.4 \\
\hline
\end{tabular}

The amount or frequency of the intake during a week

Table 8-2 Nutritional Status

(Boys)

\begin{tabular}{|c|c|c|c|c|c|}
\hline School Food & Milk & Eggs & Meat & Fish & Bean \\
\hline A & 5.7 bottle & 5.4 & 4.1 times & 3.4 times & 3.2 times \\
\hline B & 1.6 & 2.2 & 2.7 & 2.4 & 1.7 \\
\hline $\mathrm{C}$ & 1.1 & 0.4 & 1.6 & 2.7 & 2.1 \\
\hline
\end{tabular}

The amount or frequency of the intake during a week

Table 9-2. Average Physical Status of the Boys who have Already had Mutation and That of the Boys who have not yet

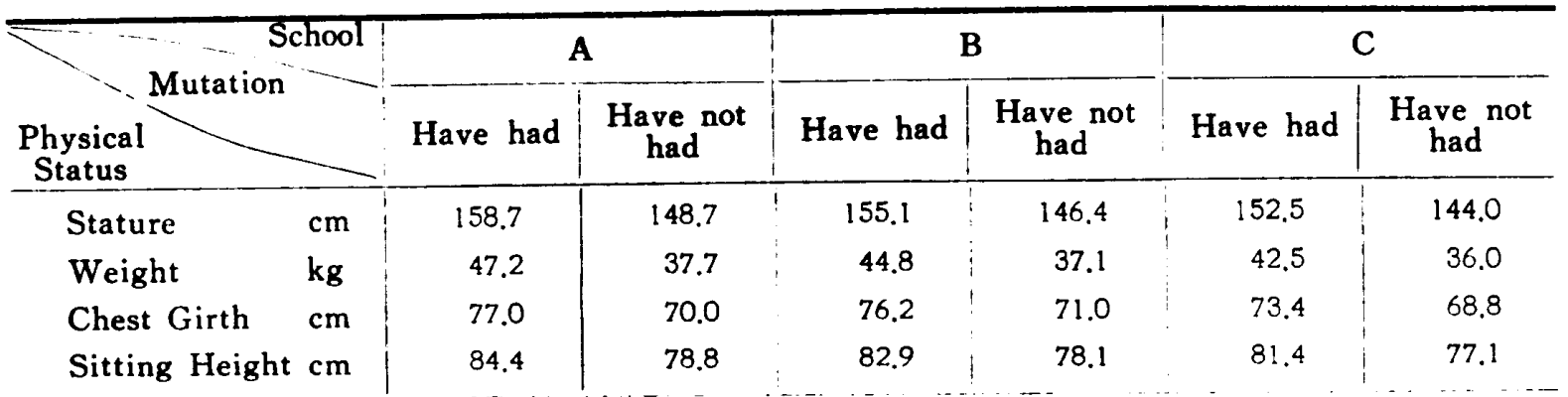

Table 9-1. Averge Physical Status of the Girls who Have Already had Menarche and That of the Girls who have not yet had Menarche

\begin{tabular}{|c|c|c|c|c|c|c|c|}
\hline & chool & & & & & & \\
\hline $\begin{array}{l}\text { Menarche } \\
\text { Physical } \\
\text { Status }\end{array}$ & & Have had & $\begin{array}{c}\text { Have not } \\
\text { had }\end{array}$ & Have had & $\begin{array}{c}\text { Have not } \\
\text { hae }\end{array}$ & Have had & $\begin{array}{c}\text { Have not } \\
\text { had }\end{array}$ \\
\hline Stature & $\mathrm{cm}$ & 1529 & $1+7.9$ & 151.1 & 147.0 & 148.5 & 144.1 \\
\hline Weight & kg & 44.4 & 37.2 & 43.4 & 38.3 & 42.0 & 36.1 \\
\hline Chest Girth & $\mathrm{cm}$ & 75.1 & 69.6 & 74.4 & 71.8 & 73.7 & 68.3 \\
\hline Sitting Heigh & $\mathrm{t} \mathrm{cm}$ & 81.0 & 78.7 & 81.8 & 77.5 & 81.1 & 77.5 \\
\hline
\end{tabular}


the other two school students, and also that of $\mathrm{B}$ school students is better than the $\mathrm{C}$ school students especially of milk, eggs and meat. We can say that those differences are important factors influencing children's growth and development.

(8) Next, we will describe briefly on the diferences between the boys and girls who have already had an emergence of the secondary sex characteristics and those who have not yet had it. The former have better physical status (Table 9), families' economic status, nutrional conditions, etc. than the later.

\section{Summary}

Summarizing, the following factors were observed in the instances of average children with excellent physical status : ealier emergence of secondary sex characteriestics, better intellignce, better financial condition of home, proper amount of physical exercise, and especially, good nutritional status.

Moreover, an inquiry in the agricultural district of another Prefecture in the eastern part of Japan showed tendency similar to that of $\mathrm{C}$ school in respect to physique, nutritional conditions, etc..

In Japan, there will be no difference in the growth and development caused only by di. fference in latitude and longtitude. If there is a regional difference, it depends upon fundamental factors, such as the ecnomy, cultural circumstances, optimal physical exercises and nutrition.

Though complicated factors influence the process of physical growth and development, it is clear that such principal factors as economy, culture, physical exercises and nutrition play an important part in growth and development.

\section{References}

1) Ministry of Edueation, Japan: Statistical Report on School Health, 1958, 1960 1963.

2) Kawahata, A. and Yagi, T.: “On the Acceleration of Growth and Development of the Japanese after the Second World War", The Humanities, Dept. of Liberal Arts, Kyoto Univ., Kyoto, Japan, Vol. X. 1964, pp. 309 340.

3) Matsuura, Y.: "Analysis of Acceleration Phenomena in Growth and Development", Research Journal of Physical Education, Vol. 8, No. 2, 1964, pp. 35 41.

i) Takai, T. and Ando, K.: "On the Acceleration of Growth and Development of Boys and Girls of our Country", The Research Report of Kinki Society of School Health, No. 5, 1963, pp. $10 \sim 17$. 